\title{
Propranolol and ascorbic acid in control of fibrodysplasia ossificans progressiva flare-ups due to accidental falls
}

\author{
Durval Batista Palhares ${ }^{1}$, Deborah Ribeiro Nascimento ${ }^{1,2}$, Marilene Garcia Palhares ${ }^{1}$, \\ Suzana Lopes Bomfim Balaniuc ${ }^{1}$, Liane de Rosso Giuliani ${ }^{1}$, Paula Cristhina Niz Xavier ${ }^{1}$, \\ José Mauro Goulart Brum ${ }^{3}$, Fabiana Alves ${ }^{4,5}$, Francisco Oliveira Vieira ${ }^{4,5}$, \\ Elaine Maria Souza-Fagundes ${ }^{4}$, Adam Underwood ${ }^{6}$, Amy Milsted $^{6}$, \\ Robson Augusto Souza Santos ${ }^{4}$, Almir Sousa Martins ${ }^{4, *}$ \\ ${ }^{1}$ UFMS/ Faculty of Medicine, Campo Grande, MS, Brazil; \\ ${ }^{2}$ Medical Faculty of Barbacena, José Bonifácio Lafayette de Andrada Foundation, MG, Brazil; \\ ${ }^{3}$ Procter \& Gamble Health Care \& Global Clinical Sciences, Mason, OH, USA; \\ ${ }^{4}$ UFMG/ Department of Physiology and Biophysics, Belo Horizonte, MG, Brazil; \\ ${ }^{5}$ Centro Universitário Metodista Izabela Hendrix- IMIH, Belo Horizonte, MG, Brazil; \\ ${ }^{6}$ The Walsh University, Division of Mathematics and Sciences, North Canton, OH, USA.
}

\begin{abstract}
Summary
Fibrodysplasia ossificans progressiva (FOP) is a rare, intractable and devastating genetic connective tissue disorder characterized by progressive ectopic ossification in the soft tissues and skeleton. Three patients, one teenage girl (P1), one male adult (P2) and one male child (P3), were studied and treated with FOPCON (combined formulation of $14 \mathrm{mg}$ of propranolol and $250 \mathrm{mg}$ of ascorbic acid), given three times per day. P1 started treatment in March 2012, P2 in October 2012 and P3 in July 2015. The clinical follow-up of these three patients, before initiating treatment with FOPCON, showed that FOP flare-ups used to occur frequently and that under FOPCON therapy, none of these patients had flareups. The striking feature of this treatment with FOPCON, is that, all three cases suffered accidental falls with documented injures until complete healing and that where major flare-ups should occur, injures or sequels, there was none. The present clinical observation shows that ascorbic acid plus the nonspecific beta blocker propranolol can be effectively useful, when administered previously and continually, in the prophylaxis of FOP flare-ups, especially for accidental falls. In this regard, FOPCON could be a prophylactic aid in cases of surgery of patients with FOP, hoping that it may benefit patients from having the severe sequels, characteristic of heterotopic bone formation. All three patients reported, to date, they no longer had flare-ups nor heterotopic ossification and showed normal scar healing.
\end{abstract}

Keywords: Vitamin C, beta blocker, ectopic ossification, FOPCON

\section{Introduction}

Fibrodysplasia ossificans progressiva (FOP, OMIM\#135100) is a rare genetic connective tissue

Released online in J-STAGE as advance publication February $22,2019$.

*Address correspondence to:

Dr. Almir Sousa Martins, Departamento de Fisiologia e Biofísica-ICB/UFMG. Av Antonio Carlos, 6627, A4-256, Belo Horizonte, MG, Brazil - 31.270-900.

E-mail: asm2011@ufmg.br disorder characterized by malformations of the hallux and progressive ectopic ossification in skeletal muscles and soft tissues. It is an autosomal dominant disease and worldwide prevalence is 1 per 2,000,000 births (1). The gene responsible for essential activation of activin receptor type-1 (ACVR1) or activin-like kinase 2 [ALK-2], was discovered in 2006 (2), in patients who had recurrent mutation of codon 206 from arginine to histidine in ACVR1, also named bone morphogenic protein (BMP) type I receptor, for activating the BMP signaling pathway $(2,3)$, and consequently responsible for inherited and sporadic FOP. 
Until today no treatment has been effectively able to control FOP disease. Progress has been achieved in inhibiting ossification, with Palovarotene, a retinoic acid receptor gamma agonist with low potential for side effects $(4,5)$. In the literature there are few other drugs (6-10). Ascorbic acid treatment case reports of FOP were previously described by Palhares et al. (1997, 2001 and 2010), showing improvement of symptoms (8), decrease of flare-ups (9) and transient stabilization of crisis (10).

Because FOP disease is prone to flare-ups (11), due to any manipulations, be they accidental trauma, surgeries, dental procedures, intramuscular injections, bacterial or viral infections and stress, it becomes impossible to control flare-ups and heterotopic ossification.

In this regard, as a novelty we report three cases of FOP patients, who had accidental falls, and were benefited by a combination therapy of ascorbic acid and propranolol (FOPCON), without flare-ups or sequels.

\section{Materials and Methods}

The present study is a comparison of three FOP patients, one teenage girl (P1), one male adult (P2) and one male child (P3). They were clinically evaluated and followed up by medical professionals, including a pediatrician, a medical geneticist, odontologists and academic researchers at the University Hospital of The Federal University of Mato Grosso do Sul and Federal University of Minas Gerais. Patients were studied and treated with FOPCON 14.250 (Fibrodysplasia ossificans progressiva combined formulation of $14 \mathrm{mg}$ of propranolol and $250 \mathrm{mg}$ of ascorbic acid), given three times per day. P1 started treatment in March 2012, P2 in October 2012 and P3 in July 2015 and are part of a project approved by the University Hospital Ethics Committee (CAAE: 60117916.0.0000.0021), upon Free and Informed Consent Form, signed by patients and their caregivers (12).

P1 was born April 2002, with diagnosis within 34 months old. Her manifestation of FOP was first described by Palhares (2010) (8). P2, born April 1984, showed clinical manifestations at 30 months of age, reported somewhere else $(9,10)$. This patient achieved adulthood and received several conventional treatments with antiinflammatories and corticosteroids during crisis and received significant therapy. Although, otherwise healthy, the patient evolved with some control of the disease including ossification and significant loss of mobility as an adult FOP patient. On October 2012, the patient was added onto FOPCON therapy only. P3 was born September 2009, with bilateral hallux valgus and his first acute FOP crisis occurred when he was 7 months old.

Before FOPCON, P1 and P2 were pretreated with ascorbic acid (AA), and obtained transient stabilization of crises, subsequently propranolol was introduced combined with AA. Both cases were previously described by Palhares $(8-10)$, featuring previous classical treatment medicines compared with the present FOPCON treatment results.

On the other hand, P3 was treated directly with FOPCON formulation. Thus, the results obtained in P3 were compared to their previous history (recorded in clinical practice) of frequent falls or traumas and consequent limitation of movement, despite the use of conventional treatments.

\section{Results and Discussion}

To our knowledge, the present report is the first demonstrating three cases of FOP patients, who had accidental falls with injuries, and were safe using a novel combination therapy (FOPCON) of AA and propranolol (PP), and showing, so far, no flare-ups or sequels from those injuries (Table 1).

P1 suffered a fall when running in the schoolyard leading to bruising, and a cut in the upper left eyebrow area, in June 2014, about two years after starting treatment. The skin was cleaned, repaired, and sutured with seven stitches. During the recovery phase after suture, there was no flare-up (Figure 1), and tissue showed normal resolution and scar healing. P1 has been maintained on FOPCON since that time and has shown good drug tolerance, normal blood pressure and no side effects. However, in 2017, P1 began taking FOPCON on an irregular schedule, and inadvertently, at the same time, the teen had a tattoo on her right arm drawn in December 2017, which consequently led to a large flare-up on each upper limb, compromising the hand on the same side of the tattoo. After re-introduction of FOPCON, the flare-up regressed, and she is doing active physiotherapy to improve the movements of the fingers, which were initially totally frozen. Currently, P1 is taking medication correctly and is clinically stabilized without any flare-up.

P2, previously treated with AA plus bisphosphonates, was added to a new treatment with FOPCON in October 2012. Since then, P2 has had no flare-up. Though P2 has vague complaints associated to pre-existing numerous ectopic ossifications, his overall status has improved significantly. Patient's blood pressure has always remained within normal limits, ranging 100/60 $\mathrm{mmHg}$. By February 2015, during domestic transportation, P2 fell from a stretcher and suffered an injury in the soft tissue of his left leg, with good healing and did not present flare-up (Figure 2). Since he started treatment with FOPCON, he has never had any FOP crisis, showing clinical improvement, better neck movement, better sleep, and excellent mouth opening, which gradually improved, since initially it was only $30 \%$. Now it's six years and four months of treatment with improvements, although he began his treatment under a bedridden condition.

P3 started FOPCON treatment in July 2015. P3 showed good tolerability to FOPCON without any 
Table 1. Clinical characteristics, previous treatments, current treatment characteristics and results for each individual case

\begin{tabular}{|c|c|c|c|c|c|c|c|}
\hline Identification & $\begin{array}{l}\text { First flare-up } \\
\text { (years/month) }\end{array}$ & $\begin{array}{l}\text { Previous } \\
\text { treatment }\end{array}$ & $\begin{array}{l}\text { Current physical } \\
\text { situation }\end{array}$ & $\begin{array}{c}\text { FOPCON } \\
\text { treatment onset }\end{array}$ & $\begin{array}{c}\text { Current } \\
\text { treatment* }\end{array}$ & Accident & Results \\
\hline \multirow[t]{2}{*}{ P1 } & $2 / 5$ & $\begin{array}{l}\text { Anti-inflammatory, } \\
\text { bisphosphonates, } \\
\text { vitamin C }\end{array}$ & $\begin{array}{l}\text { Walks with little } \\
\text { limitation }\end{array}$ & March 2012 & $\begin{array}{c}\text { FOPCON } 14.250 \\
3 x \text { per day }\end{array}$ & $\begin{array}{l}\text { March } 2014-\text { fall; } \\
\text { seven stitches in the } \\
\text { upper left eyebrow }\end{array}$ & $\begin{array}{l}\text { No flare-up, } \\
\text { normal resolution } \\
\text { and scar healing. }\end{array}$ \\
\hline & & & & & & $\begin{array}{l}\text { December } 2017 * * \\
\text { - tattoo in right arm }\end{array}$ & $\begin{array}{l}\text { Flare-up in the } \\
\text { upper limbs, } \\
\text { regressing after } \\
\text { re-introduction } \\
\text { FOPCON, without } \\
\text { ectopic bone. }\end{array}$ \\
\hline $\mathrm{P} 2$ & $2 / 6$ & $\begin{array}{l}\text { Corticosteroids, } \\
\text { analgesics, } \\
\text { bisphosphonates, } \\
\text { vitamin C }\end{array}$ & Bedridden & Oct. 2012 & $\begin{array}{l}\text { FOPCON } 14.250 \\
3 x \text { per day }\end{array}$ & $\begin{array}{c}\text { February } 2015 \\
\text { - fall; injury in the } \\
\text { soft tissue of left } \\
\text { leg }\end{array}$ & $\begin{array}{l}\text { No flare-up; } \\
\text { good healing. }\end{array}$ \\
\hline P3 & $0 / 7$ & $\begin{array}{l}\text { Corticosteroids, } \\
\text { analgesics, } \\
\text { anti-inflammatory }\end{array}$ & $\begin{array}{l}\text { Walks with } \\
\text { limitation }\end{array}$ & July 2015 & $\begin{array}{l}\text { FOPCON } 14.250 \\
3 x \text { per day }\end{array}$ & $\begin{array}{l}\text { Several falls; stiches } \\
\text { in forehead; humerus } \\
\text { fracture }\end{array}$ & $\begin{array}{l}\text { No flare-up; } \\
\text { good recovery. }\end{array}$ \\
\hline
\end{tabular}

*Dosage: FOPCON $14.250=14 \mathrm{mg}$ of propranolol and $250 \mathrm{mg}$ ascorbic acid; **irregular schedule FOPCON.

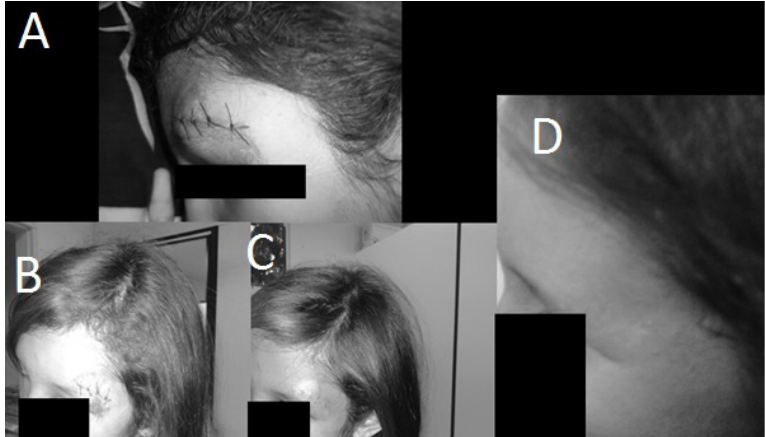

Figure 1. FOP patient 1 (P1) under treatment with FOPCON. P1 suffered a fall in the schoolyard, it was necessary to make seven stiches in the eyebrow region. (A), (B), (C) and (D) show the scar healing chronological evolution over a period of about 30 days. Scar healing evolved without FOP flare-up.

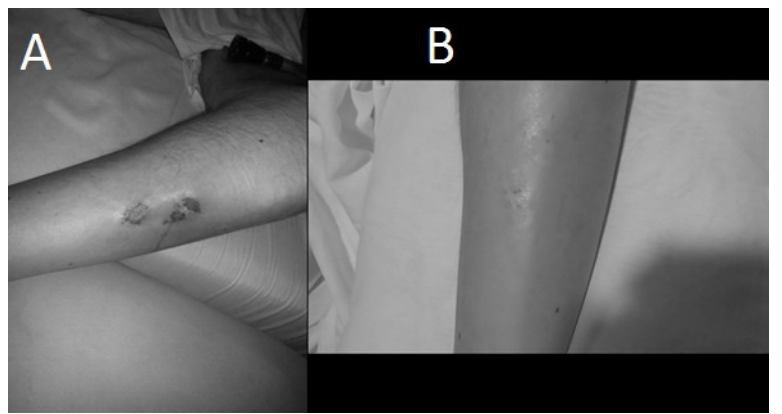

Figure 2. FOP patient 2 (P2) under treatment with FOPCON. P2 fell from the stretcher, injuring his left leg (A). The healing was natural under treatment with FOPCON. Ten months after trauma, there was no evidence of ectopic bone on the scar (B) site or elsewhere.

adverse events and normal blood pressure for his age. He has suffered several falls due to considerable limitations in the range of motion of limbs, mainly

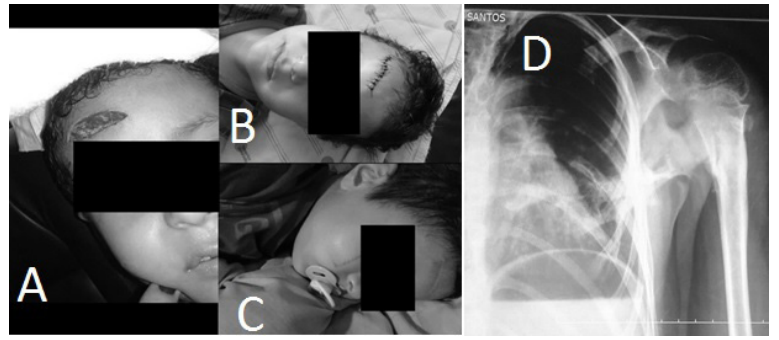

Figure 3. FOP patient 3 (P3) under treatment with FOPCON. Forehead severe injury, due to a fall, while playing at home. Under FOPCON treatment, the healing process (A), (B) and (C) was normal. There was no ectopic bone formation at the wound site or elsewhere in the body. Later, P3 had a second fall, with left humerus fracture (D). The healing process showed normal bone healing with the orthopedic treatment and did not develop disease crisis.

in the upper limbs' abduction. Typically, physical injuries or trauma in patients with severe FOP such as P3, would cause acute crisis with appearance of inflammation and swelling. However, P3 so far, shows no sign of FOP crisis. His healing evolved naturally without ectopic bone formation (Figure 3A, 3B and 3C). Later, P3 had another fall, resulting in a left humerus fracture, nevertheless, showed good recovery (Figure 3D). Recently, P3 had a left knee trauma and he had a joint effusion and pain but without FOP crisis, however parents were advised to seek orthopedic treatment.

No effective medical therapy is known for FOP, bisphosphonates and corticosteroids are only beneficial during flare-up, but do not prevent formation of ectopic bone (6). Distinct case reports reveal reasonable disease control with etidronate, including ectopic bone reduction, however, they agree that long-term use leads to osteopenia, contraindicating its continuous use 
$(13,14)$. Other groups have proposed drugs already in a clinical trial phase, however, their efficacy and side effects can be questioned $(15,16)$. The use of AA only (11) as well as AA plus intravenous bisphosphonates (10), despite some improvement in the patients, did not avoid disease progression. Therefore, although many treatments have been reported, the disease may have shown slight improvement, but disease progression has been observed, as well as recurrence of flare-ups.

FOP crisis always appears spontaneously or due to local trauma that leads to severe inflammatory responses of connective tissue and intramuscular edema in such ways that biopsies of FOP patient's tissues, with inflammatory processes, have shown formation of endochondral osteogenesis in heterotopic sites, causing ectopic ossification (11). Consequently, attempts to remove heterotopic ossification surgically have been mostly unsuccessful, since surgical trauma itself can provoke disease flare-ups. With the intent to block formation of new tissue, anti-angiogenic drugs such as thalidomide and Squalamine, have been used in FOP (17) for inhibition of new blood vessel formation, but failed to resolve the manifestation of FOP signs and symptoms.

The major rationale for the usage of betablockers comes with reports that heterotopic bone is formed along with new neurons and that enervation is important in the onset of bone morphogenesis in FOP (18). Furthermore, endochondral bone formation requires angiogenesis, so the use of propranolol may be a limiting factor in this process, because without angiogenesis, there would be no vessels to form bones (19) and beta-blockers are anti-angiogenic, while propranolol usage has shown effectiveness in the treatment of hemangiomas $(20,21)$. How FOPCON acts and interferes with bone morphogenic protein (BMP) signaling, is not known, but BMP signaling pathway is controlled by receptors types 1 and 2 in a cascade regulated at multiple levels where FOPCON may modulate.

The function of propranolol is not explained solely by these factors. Propranolol is one of the drugs indicated for cardiovascular and other clinical applications such as migraine, anxiety and glaucoma (22), and is a nonselective beta-blocker antagonist, which blocks the action of both adrenaline and noradrenalin adrenergic receptors such as $\beta 1$ and $\beta 2$. Also, propranolol can act as a partial agonist of one or more serotonin receptors $(22,23)$.

Reports on the therapeutic combination of AA and PP concomitantly are rare, which includes atrial fibrillation treatment (24) and clinical pharmacokinetics study of drug interactions (25). Nevertheless, AA has recently been shown to regulate expression of a battery of genes (26), but PP has not yet been investigated in this regard. In vivo AA modulates the expression of inflammatory genes (27) and in vitro, modulates target genes related to
FOP pathology (28).

The autonomous nervous system has been lately, strongly linked to inflammatory processes, specially the sympathetic system as a pro-inflammatory branch (29). FOP and its symptoms involve the autonomic nervous system and neurohumoral mechanisms. A neurogenic pain in FOP patients has been recently described and to be of a more intense degree than reported for the general population (30). The pain and emotional symptoms of FOP must be targeted as neuroinflammatory symptoms for clinical treatment. Our three FOP patient cases improved considerably, being free from body pain after FOPCON.

\section{Conclusion}

In conclusion, the composition of $\mathrm{AA}$ and $\mathrm{PP}$ can be effectively useful, if administered previously and continually, for prophylaxis of flare-ups due to accidental falls. FOPCON may benefit patients in future surgical procedures by preventing them from having the severe sequels characteristic of heterotopic bone formation. All three patients reported, to date, no longer had flare-ups nor heterotopic ossification and showed normal scar formation without sequalae. The monitoring of younger patients like P3, who still do not have all the heterotopic bone formation in advanced stages that immobilize most patients in bed, will allow us to see, in the coming years, the effect of FOPCON blocking the deplorable evolution of FOP.

\section{Acknowledgements}

Project supported by: Instituto de Assistência em Pesquisa, Educação e Saúde - IAPES, CG, MS, Brazil and CAPES. Present report is a project of FOP treatment study approved by University Hospital Ethics Committee (CAAE: 60117916.0.0000.0021). FOPCON is under Invention Patent: pharmaceutical compositions of propranolol and ascorbic acid and uses - Protocol number: BR1020150324928.

\section{References}

1. Pignolo RJ, Shore EM, Kaplan FS. Fibrodysplasia ossificans progressiva: Clinical and genetic aspects. Orphanet J Rare Dis. 2011; 6:80.

2. Shore EM, Xu M, Feldman GJ, et al. A recurrent mutation in the BMP type I receptor ACVR1 causes inherited and sporadic fibrodysplasia ossificans progressiva. Nat Genet. 2006; 38:525-527.

3. Morales-Piga A, Bachiller-Corral J, Trujillo-Tiebas MJ, Villaverde-Hueso A, Gamir-Gamir ML, AlonsoFerreira V, Vázquez-Díaz M, Posada de la Paz M, AyusoGarcia C. Fibrodysplasia ossificans progressiva in Spain: Epidemiological, clinical, and genetic aspects. Bone. 2012; 51:748-755.

4. Shimono K, Tung W, Macolino C, Chi A.H, Didizian JH, Mundy C, Chandraratna RA, Mishina Y, Enomoto- 
Iwamoto M, Pacifici M, Iwamoto M. Potent inhibition of heterotopic ossification by nuclear retinoic acid receptor- $\gamma$ agonists. Nat Med. 2011; 17:454-460.

5. Clementia initiates Phase 2 extension study of palovarotene in FOP patients. News Medical Life Sciences. 2014. http://www.news-medical.net/ news/20141027/Clementia-initiates-Phase-2-extensionstudy-of-palovarotene-in-FOP-patients.aspx (accessed May 05, 2018).

6. Kaplan FS, Shore EM, Pignolo RJ (eds). The medical management of fibrodysplasia ossificans progressiva: current treatment considerations. International Clinical Consortium on Fibrodysplasia Ossificans Progressiva. 2011; 4:1-100. http://fundacionfop.org.ar/wp-content/ uploads/2015/09/the-medical-management.pdf (accessed May 05, 2018).

7. Katagiri T, Tsukamoto S, Nakachi Y, Kuratani M. Recent topics in fibrodysplasia ossificans progressiva. Endocrinol Metab (Seoul). 2018; 33:331-338.

8. Palhares DB, Leme LM, Naka EM, Melnikov P. Fibrodysplasia ossificans progressiva: Oral ascorbate and intravenous bisphosphonate during flare-ups. J Musculoskelet Pain. 2010; 18:270-276.

9. Palhares DB. Myositis ossificans progressive. Calcif Tissue Int. 1997; 60:394.

10. Palhares DB, Leme LM. A perspective on the control of myositis ossificans progressiva. J Pediatr (Rio J). 2001; 77:431-444. (in Portuguese)

11. Kaplan FS, Tabas JA, Gannon FH, Finkel G, Hahn $\mathrm{GV}$, Zasloff MA. The histopathology of fibrodysplasia ossificans progressiva. An endochondral process. J Bone Joint Surg Am. 1993; 75:220-230.

12. Palhares MG, Nascimento DR, Giuliani LR, Xavier PCN, Nascimento VA, Martins AS, Palhares DB. Clinical reports of 31 brazilian case presentations with fibrodysplasia ossificans progressiva. Int J Dev Res. 2018; 8:18315-18320.

13. Nucci A, Queiroz LD, Santos AD, Camargo EE, MouraRibeiro MV. Fibrodysplasia ossificans progressiva: Case report. Arq Neuropsiquiatr. 2000; 58:342-347.

14. Fonseca JE, Branco JC, Reis J, Evangelista T, Tavares V, Gomes AR, Queiroz MV. Fibrodysplasia ossificans progressiva: Reporto f two cases. Clin Exp Rheumatol. 2000; 18:749-752.

15. Kaplan FS, Zeitlin L, Dunn SP, Benor S, Hagin D, Mukaddam MA, Pignolo RJ. Acute and chronic rapamycin use in patients with fibrdysplasia ossificans progressiva: A report of two cases. Bone. 2018; 109:281284.

16. Lees-Shepard JB, Nicholas SE, Stoessel SJ, Devarakonda PM, Schneider MJ, Yamamoto M, Goldhamer DJ. Palovarotene reduces heterotopic ossification in juvenile FOP mice but exhibits pronounced skeletal toxicity. Elife. 2018; 7.pii:e40814.

17. Kaplan FS, Glaser DL, Pignolo RJ, Shore EM. A new era for fibrodysplasia ossificans progressiva: A druggable target for the second skeleton. Expert Opin Biol Ther. 2007; 7:705-712.
18. Salisbury E, Sonnet C, Heggeness M, Davis AR, Olmsted-Davis E. Heterotopic ossification has some nerve. Crit Rev Eukaryot Gene Expr. 2010; 20:313-324.

19. Sommers Smith SK, Smith DM. Beta blockade induces apoptosis in cultured capillary endothelial cells. In Vitro Cell Dev Biol Anim. 2002; 38:298-304.

20. Léauté-Labrèze $C$, Taïeb $A$. Efficacy of beta-blockers in infantile capillary haemangiomas: the physiopathological significance and therapeutic consequences. Ann Dermatol Venereol. 2008; 135:860-862. (in French)

21. Lowenthal DT, Saris SD, Packer J, Haratz A, Conry K. Mechanisms of action and the clinical pharmacology of beta-adrenergic blocking drugs. Am J Med. 1984; 77:119127.

22. Black JW, Crowther AF, Shanks RG, Smith LH, Dornhorst AC. A new adrenergic beta receptor antagonist. Lancet. 1964; 1:1080-1081.

23. Yamamura HI, Horita A. Effect of propranolol on the blockade of alpha adrenergic receptors. J Pharmacol Exp Ther. 1968; 164:82-89.

24. Eslami M1, Badkoubeh RS, Mousavi M, Radmehr H, Salehi M, Tavakoli N, Avadi MR. Oral ascorbic acid in combination with beta-blockers is more effective than beta-blockers alone in the prevention of atrial fibrillation after coronary artery bypass grafting. Tex Heart Inst J. 2007; 34:268-274.

25. Gonzalez J, Valdivieso A, Calvo R, Rodríguez-Sasiaín JM, Jimenez R, Aguirre C, du Souich P. Influence of vitamin $\mathrm{C}$ on the absorption and first pass metabolism of propranolol. Eur J Clin Pharmacol. 1995; 48:295-297.

26. Belin S, Kaya F, Burtey S, Fontes M. Ascorbic Acid and gene expression: another example of regulation of gene expression by small molecules? Curr Genomics. 2010; 11:52-57.

27. Canali R, Natarelli L, Leoni G, Azzini E, Comitato R, Sancak O, Barella L, Virgilli F. Vitamin C supplementation modulates gene expression in peripheral blood mononuclear cells specifically upon an inflammatory stimulus: A pilot study in healthy subjects. Genes Nutr. 2014; 9:390.

28. Ribeiro DR, Palhares DB, Del Puerto HL, Alves F, Martins SF, Vieira FO, Brum JMG, Giuliani LR, Palhares MG, Souza-Fagundes EM, Underwood A, Milsted A, Santos RAS, Martins AS. Ascorbic acid modulates the expression of genes involved in heterotopic ossification. NBC-Periódico Científico do Núcleo de Biociências. 2017; 7:81-97.

29. Olofsson PS, Rosas-Ballina M, Levine YA, Tracey KJ. Rethinking inflammation: neural circuits in the regulation of immunity. Immunol Rev. 2012; 248:188-204.

30. Kitterman JA, Strober JB, Kan L, Rocke DM, Cali A, Peeper J, Snow J, Delai PL, Morhart R, Pignolo RJ, Shore EM, Kaplan FS. Neurological symptoms in individuals with fibrodysplasia ossificans progressiva. J Neurol. 2012; 259: 2636-2643.

(Received September 8, 2018; Revised January 26, 2019; Accepted February 4, 2019) 